\title{
ISLAM DAN WARISAN KESENIAN KESULTANAN PALEMBANG DARUSSALAM
}

\author{
Ryllian Chandra \\ Dosen Prodi Politik Islam, Fakultas Adab dan Humaniora \\ UIN Raden Fatah Palembang
}

\begin{abstract}
Abstrak
Artikel ini mendiskusikan keterkaitan antara Islam dan kesenian pada kebudayaan yang terwariskan dari Kesultanan Palembang Darussalam. Islam seringkali dijadikan sebagai penyebab utama dari minimnya kesenian pada kebudayaan asli Palembang. Penjelasan tersebut tidaklah memuaskan sehingga diperlukan hipotesa lain untuk menelisik dan mencari faktor lain yang dapat menerangkan bagaimana konstruksi kesenian Palembang. Dinamika politik, ekonomi, dan sosial ikut mempengaruhi hadirnya kesenian, sehingga agama tidak dapat dianggap sebagai penghalang bagi perkembangan kesenian.

This article discusses the interrelationship between Islam and arts in the culture which is inherited from Sultanate of Palembang Darussalam. Islam is often used as the main cause of the lack of art in the original culture of Palembang. The explanation is not satisfactory so another hypothesis is needed to probe and look for other factors that can explain how the construction of Palembang art legacy. Political, economic, and social dynamics influence the presence of art, so religion could not be considered as a barrier to the development of art.
\end{abstract}

Keywords : cultural representation, Islamic art, Sultanate of Palembang Darussalam.

Di masa Kesultanan Palembang Islam dijalankan dengan begitu ketat, tidak hanya ritual, namun juga institusionalisasi hukum islam dalam peraturan di kesultanan. Imbas dari ajaran yang ketat tersebut ialah kesenian dibatasi karena tidak sejalan dengan ajaran Islam. Pembatasan di masa kesultanan tersebut pada akhirnya disederhanakan menjadi pembenaran atas begitu minimnya kesenian tradisional asli Palembang sekarang ini. Penelitian ini salah satunya beranjak dari kritik terhadap dugaan sederhana yang menyimpulkan bahwa Islam menjadi penyebab utama begitu minimnya kesenian di Palembang. Variabel lain yang diajukan dan hendak dijelaskan dalam tulisan ini ialah bahwa perubahan ekonomi yang diakibatkan perubahan politik telah berimbas pada kedudukan sosial kelompok priyayi sebagai agen utama pemegang tradisi dan budaya kesultanan.

\section{Apakah Islam Membatasi Kesenian?}

Dalam Musical Journey in Sumatra, Kartomi mendapat keterangan dari seorang keturunan kesultanan yakni R.H.M. Nato Dirajo yang berpendapat mengenai begitu minimnya kesenian di Kesultanan Palembang akibat pengaruh Islam yang melarang kesenian, terutama dalam bentuk tarian, untuk dipraktekan hidup di lingkungan keraton, sehingga kesenian yang dapat hidup hanyalah gamelan jawa dan wayang kulit purwa. Alasannya karena dalam pertunjukannya terdapat bagian di mana sang dalang melantunkan syair pujian dalam bahasa arab yang menceritakan kisah tokoh-tokoh 
Islam termasuk Wali Songo meskipun cerita yang dipertunjukan wayang di keraton Kesultanan Palembang, sama seperti pertunjukan lainnya di Jawa, Pandawa Lima lengkap dengan panakawan seperti Semar, Petruk, dan Gareng adalah yang paling populer di istana. Sebagai pelengkap sakralitas pertunjukan, sebuah upacara ritual diadakan setiap kali wayang akan dipertunjukan. ${ }^{1}$

Penjelasan yang terlampau sederhana tersebut memunculkan pertanyaan apakah Islam yang dianut oleh lingkungan kraton Palembang, yang Kartomi tulis sebagai UltraMuslim, menjadi faktor utama begitu terbatasnya kesenian karena adanya larangan atas segala bentuk kesenian, terutama kesenian yang dibawakan oleh perempuan dan masih terdapat unsur ajaran nenek moyang. Ataukah ada faktor lain yang menyebabkan miskinnya kesenian asli Palembang apalagi jika kita melihat di daerah bekas kesultanan Islam lainnya yang masih mempunyai kesenian asli yang terlestarikan. Oleh karena itu, dibutuhkan hipotesa dan pembuktian lainnya untuk dapat memberikan penjelasan tentang bentuk budaya dan kesenian yang berelasi dengan eksistensi Kesultanan Palembang Darussalam.

Menurut legenda, gamelan dan wayang kulit dapat menyebar ke Palembang terkait dengan relasi yang erat antara Kesultanan Palembang dan Kesultanan Demak. Di antara kedua kesultanan terjalin hubungan politik dan ekonomi yang baik. Dari hubungan bilateral tersebut, penguasa Demak menghadiahi Sultan Palembang dengan gamelan slendro-pelog dan satu set wayang kulit purwa (kemudian dikenal sebagai Wayang Palembang) untuk dihadiahkan kepada Sultan Palembang. Tidak hanya menghadiahkan, para seniman dari Demak juga dikirim ke Palembang untuk mengajarkan abdi istana bagaimana cara memainkan gamelan untuk mengiringi pertunjukan wayang. ${ }^{2}$

Akan tetapi, hal yang nampaknya sedikit dilupakan ialah bahwa gamelan dan wayang dari Demak dipertunjukan bukan sekadar kesenian semata. Melampaui seni, gamelan dan wayang dapat menyebar sebagai bagian dari islamisasi yang awalnya berpusat di Pesisir Jawa. Gamelan diperkirakan telah ada di Jawa sejak abad ke-9 masehi di mana alat musik gamelan tergambarkan pada relik di Candi Borobudur. Selain itu, beberapa bukti permainan gamelan yang berbentuk ansambel tergambar pada lukisan di Banten, Tuban, dan Mataram dari abad ke-16 dan abad ke-17. Menurut tradisi Jawa, gamelan tumbuh pada abad ke-16 selama awal islamisasi di Jawa yang saat itu berpusat di Demak. Masyarakat di Jawa percaya bahwa para Wali menjadi aktor utama berkembangnya ansambel gamelan di tanah Jawa, permainan gamelan sebagai salah satu metode persuasif islamisasi. Dalam budaya Jawa pra-Islam, gamelan adalah sesuatu yang sakral sehingga dimainkannya gamelan selalu mengiringi ritual keagamaan. Saat awal penyebaran Islam, gamelan dimainkan di dekat masjid untuk menarik penduduk sekitar datang, orang-orang itu kemudian diminta untuk berwudhu lalu mengucapkan dua kalimat syahadat sebagai konfirmasi kesukarelaannya untuk memeluk agama Islam. $^{3}$

Kesakralan gamelan pada budaya Jawa pra-Islam ditransformasi melalui nilainilai keislaman sehingga kemudian penggunaannya diinisiasi pada acara-acara sakral atau perayaan dari budaya Islam. Perayaan Maulid Nabi Muhammad SAW yang digelar

\footnotetext{
${ }^{1}$ Margaret J. Kartomi. Musical Journey In Sumatera (Chicago : University of Illinois, 2012). h, 177

${ }^{2}$ Kartomi. Musical Journey... h,178

${ }^{3}$ Sumarsam. "Past and Present Issues of Islam Within the Central Javanese and Wayang Kulit" dalam David D Harnish dan Anne K Rasmussen. Divine Inspirations : Music and Islam in Indonesia (New York : Oxford University Press, 2011), h, 48-49.
} 
selama seminggu dalam budaya Jawa disebut gerebeg, salah satunya digelar untuk mengganti acara ritual yang biasa dilakukan masyarakat Jawa pra-Islam. Dalam acara gerebegan tersebut, gamelan dimainkan dan nilai kesakralan pada instrumen tersebut membuat gamelan menjadi barang pusaka.

Sementara itu, nilai keislaman pada wayang kulit yang diiringi oleh gamelan bukan cuma terletak pada bagian di mana cerita nabi dan wali dipertontonkan disertai lantunan islami berbahasa Arab dari Sang Dalang seperti yang berada di Kesultanan Palembang. Penjelasan yang Kartomi dapatkan agaknya terlalu sederhana untuk mengurai spiritualitas dan sakralitas mistik Islam pada pertunjukan wayang kulit. Wayang kulit dan gamelan berkembang melalui islamisasi di mana materi dan ajaran Islam diserap dan bercampur dengan budaya lokal. Hibridasi budaya memungkinkan terjadi karena pengaruh sufisme di masa awal islamisasi di Nusantara. Analogi kosmologi menjadi penjelasan umum arti simbol dalam wayang. Muslim Jawa percaya bahwa dalang merepresentasikan Pencipta, dan manusia sebagai makhluk yang diciptakannya tidak lebih dari bayangan pada layar pertunjukan. Makna ini hanya dimengerti ketika seseorang melihat pertunjukan wayang kulit sebagai penggambaran dari cara Tuhan bertindak dan bekerja di dunia ini. ${ }^{4}$

Di samping itu, sufisme Islam mempengaruhi bagaimana wayang diciptakan dan karakter setiap tokoh pewayangan diberikan. Bentuk Wayang kulit Jawa pada dasarnya adalah hasil negosiasi dan adaptasi ajaran Islam. Di mana salah satu pengaruh negosiasi tersebut pada perubahan penggambaran anatomi manusia pada sosok wayang, bentuk wayang kemudian dirubah dari tiga dimensi menjadi dua dimensi, bentuknya menjadi lebih mirip makhluk khayalan dengan tangan yang panjang, mata yang bulat besar, hingga warnanya yang setiap warnanya mencerminkan karakter. Sementara itu, meskipun cerita pewayangan banyak bersumber dari cerita Hindu, detail cerita mengalami modifikasi setelah Islam masuk. Perjalanan sufistik dalam pencarian kebajikan dan segala hambatannya disimbolkan dan direpresentasikan dalam rupa peristiwa dan adegan. Inkorporasi Islam dalam wayang semakin kental ketika pusat kekuasaan Jawa-Islam berpindah dari pesisir ke Mataram. Sumber cerita pewayangan tidak lagi hanya dari kisah Hindu seperti Mahabrata, cerita-cerita dari literatur Islam pun kemudian diangkat. ${ }^{5}$

Penjelasan tersebut sedikitnya menerangkan mengapa kesenian dari Kesultanan Palembang yang dikenal hanyalah gamelan dan wayang kulit, sementara mengenai tarian masih belum jelas. Meskipun demikian, penjelasan lainnya harus dicari untuk membuktikan apakah Islam yang dianut oleh lingkungan kraton Palembang, yang Kartomi tulis sebagai Ultra-Muslim, menjadi faktor utama begitu terbatasnya kesenian karena adanya larangan atas segala bentuk kesenian, terutama kesenian yang dibawakan oleh perempuan dan masih terdapat unsur ajaran nenek moyang. Ataukah ada faktor lain yang menyebabkan miskinnya kesenian asli Palembang apalagi jika kita melihat di daerah bekas kesultanan Islam lainnya yang masih mempunyai kesenian asli yang terlestarikan.

\section{Kesultanan Palembang, Islam, dan Ruang Kesenian}

Penelusuran selanjutnya mengenai bagaimana Islam di Kesultanan Palembang. Di lingkungan keraton Kesultanan Palembang yang berorientasi kepada kebudayaan keraton Jawa, agama Islam mempunyai kedudukan terhormat. Penguasa awal di

\footnotetext{
${ }^{4}$ Sumarsam. "Past and Present Issues of Islam..." h, 58

${ }^{5}$ Sumarsam. "Past and Present Issues of Islam..." h, 53
} 
Kesultanan Palembang, Ki Hindi, pada abad ke-17 setelah memutuskan hubungan dengan Mataram dan mengangkat dirinya sejajar dengan penguasa Jawa, ia merengkuh legitimasi melalui simbol otoritas Islam. Ki Hindi mengubah namanya menjadi Sultan Abdulrahman dan menyandang gelar Kholifatul Mukminin Sayidul Iman. Dengan demikian Islam menjadi agama Kesultanan Palembang dan pelaksanaan hukum Islam diserap dalam struktur kesultanan melalui pemakaiannya untuk mengelola pemerintahan di kesultanan. ${ }^{6}$

Meskipun demikian tidaklah dapat disimpulkan bahwa Islam di Kesultanan Palembang dijalankan secara holistik dan konstan. Jeroen Peeters melalui bukunya Kaum Tuo - Kaum Mudo menjelaskan perkembangan Islam di Palembang sejak era Kesultanan Palembang yang menggambarkan proses islamisasi berjalan terjadi melalui beberapa gelombang dengan efek yang beragam. Peeter mengutip sumber yang berasal dari berbagai laporan para pegawai Belanda sebelum dan setelah Kesultanan Palembang diabolisi pada 1824 oleh Pemerintah Kolonial Belanda. Penilaian tentang perilaku keagamaan penduduk Palembang lebih banyak berasal dari kalangan kolonial, bukan berasal dari sumber-sumber orang Islam atau penduduk Palembang sendiri sehingga memungkinkan terlalu subjektifnya penilaian. Meskipun demikian, dari sumber-sumber kolonial tersebut sedikitnya dapat menggambarkan bagaimana ajaran Islam dijalankan oleh penduduk Palembang setelah Kesultanan Palembang dihapuskan.

Laporan mengenai praktek keagamaan di Palembang muncul menjelang dihapusnya kesultanan Palembang melalui laporan Komisaris Belanda di Palembang, J.L. van Sevenhoven. Laporan ini tidak dapat sepenuhnya diandalkan karena terdapat subjektifitas pejabat kolonial. Saat itu diterangkan bahwa masyarakat Palembang pada umumnya telah beragama Islam dan sedikitnya mempraktekan ajaran Islam dalam acara khitanan, perkawinan, dan upacara lainnya. Akan tetapi sebagian besar kehidupan spiritual masyarakat Palembang masih sangat didominasi oleh segala yang bersifat takhayul baik yang terwarisi dari kepercayaan Jawa maupun yang hidup dari mitosmitos setempat. Komisaris Belanda tersebut sampai menulis dalam laporannya, "orangorang Palembang hanya namanya saja yang Islam". ${ }^{7}$

Dari beberapa laporan selama peralihan dari periode kesultanan ke periode Hindia Belanda dapat dilihat jarak yang cukup lebar antara struktur kekuasaan yang didasarkan atas keinginan mengadakan adaptasi ajaran agama dengan sistem hukum yang telah ada dengan pola perilaku pribadi dan relasi sosial. Islam tampaknya lebih merupakan agama para pendatang, serta menjadi sumber pengetahuan dan inspirasi bagi golongan priyayi. Akan tetapi, proses internalisasi nilai keislaman tersebut menimbulkan gradasi dari pusatnya di keraton yang semakin jauh pengaruhnya akan semakin memudar. Secara resmi ketentuan pengaturan kehidupan beragama menjadi tugas keraton, namun langkah konkret pengaturan tersebut tidak terlaksana sebagaimana yang diharapkan.

Laporan mengenai peningkatan kesalehan masyarakat Palembang baru terlihat setelah 1850 pada laporan yang berasal dari kalangan pegawai Belanda yang berpendapat bahwa penduduk kota bersikap sangat saleh, dan taat memenuhi kewajiban agama meraka. Animo keagamaan penduduk Palembang semakin meningkat beberapa dekade kemudian. Baru pada 1880-an, pegawai Belanda memakai istilah "fanatik"

${ }^{6}$ Djohan Hanafiah. Melayu-Jawa : Ciri Budaya dan Sejarah Palembang .Jakarta : PT Raja Grafindo Persada bekerja sama dengan Pemerintah Daerah TK II Kotamadya Palembang, 1995 h, 197.

${ }^{7}$ Jeroens Peeters. Kaum Tuo - Kaum Mudo : Perubahan Religius di Palembang 1821-1942 (Jakarta : INIS, 1997) h, 6. 
untuk menggambarkan sikap keagamaan penduduk Palembang. Antusiasme keislaman yang cukup besar terlihat pada acara-acara peribadatan dan hari-hari besar Islam yang ramai diikuti oleh para penduduk Palembang.

Sampai di sini sedikitnya ada hal yang dapat diajukan. Laporan peningkatan kesalehan masyarakat Palembang justru meningkat setelah Kesultanan Palembang lenyap. Terdapat kemungkinan bahwa keislaman di masa kesultanan Palembang tidak sefanatik atau jika pun ada hanya berlaku di lingkungan keraton, yang justru menarik kesalehan di kalangan masyarakat biasa meningkat setelah kesultanan runtuh. Meningkatnya kesalehan tersebut dapat ditelisik pada gelombang islamisasi yang dialami Palembang pada paruh kedua abad kesembilanbelas yang salah satu penandanya ialah pengaruh golongan Hadrami yang meningkat di antara masyarakat Palembang.

Sementara itu di ruang-ruang kesenian di Palembang menjadi terbuka atas pengaruh budaya-budaya lain sebagai akibat memudarnya pengaruh keraton di masyarakat. Sehingga variabel lainnya yang layak diperiksa ialah mengenai peran kalangan priyayi dalam menjaga nilai dan simbol kekuasaan Kesultanan Palembang. Kesenian-kesenian yang berasal dari adaptasi kesenian daerah lain masuk lalu dimainkan dan hidup di tengah masyarakat Palembang, yang notabene tidak melulu kesenian islami. Sehingga bentuk kesenian yang menampilkan tarian atau penyerapan budaya yang terwariskan dari budaya non Islam bukan semata karena pembatasan dari ajaran Islam yang beredar di keraton Palembang. Dalam menelisik kembali hipotesa begitu terbatasnya kesenian di Palembang maka proses kebudayaan layak selanjutnya dialamatkan pada lapisan atas masyarakat yang dihuni oleh para keluarga sultan dan kalangan priyayi.

\section{Seni, Basis Material, dan Praktik Kekuasaan}

Menurut catatan Residen Palembang C.F.E Praetorius (1799-1846) yang datang ke Palembang beberapa tahun setelah dihapuskannya otoritas kesultanan, menerangkan bahwa di masa kesultanan masih berkuasa, terdapat dua puluh lima musisi yang hidup sebagai seniman keraton, bertugas melakukan pertunjukan gamelan khusus untuk kalangan istana. Para seniman ini tinggal di sekitar keraton, ditunjuk oleh sultan untuk merawat, memainkan, dan mengajarkan permainan gamelan sebagai imbalan mendapatkan keistimewaan dapat tinggal di dekat keraton. Mereka juga biasa bekerja sama dengan para pandai besi dari kampung lainnya yang menempa instrumen musik pengganti untuk pertunjukan gamelan dan memeriksa akurasi nada pada gamelan. Sementara kaum perempuan di sekitar istana bekerja menenun pakaian yang digunakan oleh perempuan bangsawan untuk dikenakan pada upacara, pernikahan, dan tarian. ${ }^{8}$

Kehadiran instrumen musik di Kesultanan Palembang menunjukan perbedaan lapisan materi teknologi yang merefleksikan lapisan-lapisan pengaruh budaya. Sumber daya dan teknologi khusus yang mahal dibutuhkan untuk mengolah perunggu mencerminkan nilai sosialnya yang lebih besar dan menggambarkan tidak hanya pengaruh budaya, tapi juga lapisan kelas sosial. Sumber daya dan teknik kemampuan tertentu diperlukan untuk dapat mengolah perunggu dan kepemilikannya pun hanya dipunyai masyarakat kelas atas. Instrumen yang berasal dari perunggu seperti gong terasosiasi pada ritual untuk menjaga keteraturan kosmos yang hirarkis, mencerminkan tatanan sosial dengan adanya kelas yang lebih tinggi dan lebih rendah. Keahlian teknis diperlukan dalam pembuatan instrumen musik perunggu dari para pengrajin khusus

\footnotetext{
${ }^{8}$ Kartomi. Music in Sumatra... h,179
} 
yang bekerja atas permintaan patronnya yang berasal dari kelas atas. Instrumeninstrumen musik perunggu melengkapi ritual megah yang menampilkan alat musik dan kostum yang rumit, seperti upacara pemakaman, ritus kesuburan, atau perayaan kemenangan perang. ${ }^{9}$

Dimainkannya wayang kulit dan gamelan di keraton Kesultanan Palembang tidak menjadikan kesenian tersebut menjadi kesenian rakyat. ${ }^{10}$ Kesenian yang dimainkan di keraton sifatnya ekslusif hanya dimainkan di hadapan kalangan istana pada waktu-waktu tertentu karena nilai-nilai kesakralan pada tarian dan musik yang dimainkan di istana tersebut tidak diperbolehkan dimainkan oleh masyarakat biasa. Selain itu, eksklusivitas kesenian kraton terkait usaha dan kepentingan para keturunan keluarga sultan, dalam hal ini ialah kalangan para priyayi, untuk dapat mempertahankan kesenian istana sebagai penunjuk status sosial dan nilai-nilai keluhuran keraton.

Kesenian dalam hal ini menjadi penanda kekuasaan dan status yang diperoleh melalui gaya hidup dan kekayaan. Gaya hidup dan kesenian yang dipertunjukan menjadi salah satu penanda yang paling signifikan dari kelompok bangsawan di mana kapital dan gaya hidup kemudian mampu terpancar dengan jelas menjadi penanda kelas sosial. Menghabiskan kekayaan melalui ritual dan pagelaran kesenian adalah cara untuk membedakan kelas tersebut dari kelas masyarakat lainnya. Kesenian di lingkungan kraton menjadi sebuah kapital penopang kekuasaan. Seperti yang dijelaskan Bourdieu, bahwa budaya dapat berwujud namun seringkali tidak dapat dipindahtangankan sebagaimana kemampuan memainkan alat musik. Sekaligus terinstitusinya kesenian sebagai penunjukkan latar belakang dan eksistensi satu pihak yang berpengaruh pada pihak lainnya.

Hadirnya kesenian dalam budaya melayu tidak hanya dimaknai sebagai kesenian semata namun kesenian menjadi bagian dari representasi identitas, simbol kekuasaan, nilai-nilai spiritual, dan menggambarkan lapisan sosial pada basis materialnya. Menurut sosiolog, Pierre Bourdieu dalam bukunya Distinction, budaya dan gaya hidup menjadi sebuah faktor pembeda dan modal akan terbentuknya stratifikasi sosial yang ditentukan oleh kepemilikan mereka akan kapital budaya bersamaan dengan kepemilikan kapital sosial dan kapital ekonomi. Kapital budaya diakumulasi untuk membedakan orang tersebut dari strata sosial yang ada di bawahnya. Selain ekonomi dan sosial, budaya juga menjadi modal sekaligus alat tukar di antara anggota masyarakat yang ada dan dipandang sebagai salah satu penentu yang cukup penting. Kapital budaya sendiri dapat berupa pengetahuan, kesenian, keahlian, pendidikan, dan keunggulan lain, seperti aksesibilitas dan kemampuan berbahasa. Kapital budaya berpengaruh besar dalam kehidupan dan seni pun perlahan menjadi bagian dari kapital budaya yang dipamerkan untuk sebuah pembedaan. ${ }^{11}$

Sementara itu menurut Phillip V. Bohlman, kesenian menjadi representasional karena kesenian juga merepresentasikan ritus dan spritualitas dalam masyarakat. Dalam hal ini seni sangat penting sebagai alat untuk mewakili yang sakral, memediasi jarak antara dunia sekuler dan suci. Oleh karena itu hampir setiap budaya dan agama mengenali atribut suci yang dilekatkan dalam kesenian. Ketika kesenian seperti musik

\footnotetext{
${ }^{9}$ Henry Spiller. Gamelan : The Traditional Sounds of Indonesia (California : ABC CLIO, 2004) h, 7

${ }^{10}$ Kartomi. Musical Journey in Sumatra... h, 182

${ }^{11}$ Pierre Bourdie. Distinction : A Social Critique of The Judgement of Taste (translated by Richard Nice) (Cambridge : Harvard University Press, 1984)
} 
dapat menggairahkan, menguatkan doa, atau menyertai pertunjukan teks suci, seni berfungsi untuk mewakili yang sakral. ${ }^{12}$

Kesenian merepresentasikan sakralitas dengan dua cara yang berbeda. Cara pertama sebagai medium, dalam artian bahwa musik dipahami untuk menempati ruang antara dunia sehari-hari dan suci, dan berfungsi untuk mengubah makna-makna sakral sehingga dipahami pada tingkat yang lebih manusiawi setiap hari. Cara yang kedua di mana musik mewakili yang sakral adalah dengan meningkatkan kejelasan suara kesucian. Karena alasan inilah musik jarang absen dari pertunjukan teks-teks yang diwahyukan, seperti Al Qur'an dalam Islam.

Kesenian berkontribusi pada apa yang disebut pembangunan identitas diri dan merepresentasikannya. Kesenian dapat mewakili identitas yang sangat individual atau identitas kelompok yang mengekspresikan budaya umum kolektif yang lebih besar. Ekspresi identitas melalui musik adalah suatu paradoks bahwa identitas diri tidak imanen atau asli, tapi memang imajiner. Arti identitas diri dalam seni lebih bergantung pada bagaimana menggambarkan diri, bukan dari apa sebenarnya diri itu. Terdapat semacam investasi dalam membangun identitas diri dengan seni, dan investasi itu paling jelas saat kesenian membentuk identitas diri secara historis semakin berbeda dari identitas pihak lain.

\section{Kedudukan Priyayi Palembang}

Sebelum dihapusakannya Kesultanan Palembang pada 1924, iklim sosial politik di Palembang dikuasai oleh raja dan lingkungan keraton sebagai pusat kerajaan. Kesultanan di masa berkuasanya berusaha mengontrol produksi dan distribusi. Monopoli kesultanan atas perekonomian di wilayah kesultanannya salah satunya diaplikasikan dalam sistem tiban tukon yang dikenakan kepada petani yang masuk wilayah Kepungutan dan Sikep. Dalam sistem tiban tukon, penduduk di wilayah kepungutan dan sikep sebagai abdi sultan diharuskan menanam tanaman yang sudah ditentukan oleh pihak kesultanan, 'menjual'nya melalui Jenang atau Pasirah untuk dibawa ke ibukota kesultanan untuk kemudian dijual ke pasar internasional. Melalui sistem tiban, masyarakat pedalaman menukar komoditasnya dengan garam atau tekstil, dan kebutuhan lainnya yang pendistribusiannya diatur oleh jenang dan pasirah. Sementara dalam sistem tukon, komoditas dibeli dengan uang namun biasanya uang yang dibayarkan oleh Jenang atau Pasirah di bawah harga pasaran. Baik jenang atau pasirah pada dasarnya adalah peran yang diperoleh kalangan priyayi. Selain dari pembelian hasil pertanian, sumber penghasilan priyayi juga berasal dari tugasnya sebagai pelaksana kekuasaan sultan dalam monopoli perdagangan timah Bangka dan bea atas perdagangan antar pulau. ${ }^{13}$

Bagian yang diterima sultan melalui sistem upeti, pajak, dan pengerahan tenaga penduduk (matagawe) bagi keperluan sultan sebenarnya tidak sedemikian banyak. Sebelum jatuh ke tangan pribadi sultan, bagian terbesar masuk ke kantong-kantong priyayi yang mendapatkan jabatan. Dengan kata lain, baik pemakaian kerja maupun upeti yang masuk ke kas kesultanan, terlebih dipotong persenan bagi para pejabat yang dilewati oleh prosedur tersebut. Hal ini terjadi karena keuangan di kesultanan tidak dilakukan secara terpusat, tidak ada penggajian seperti yang dikenal pada organisasi

12 Philip V. Bohlman. "Music as Representation", dalam Journal of Musicological Research, 24:3-4, 2005.

${ }^{13}$ Bambang Purwanto. From Dusun To Market : Native Rubber Cultivation in Southern Sumatra, 18901940 (PhD Thesis in School of Oriental and African Studies, University of London, 1992) h, 29. 
modern. Untuk membiayai keperluan pribadi atau keperluan jabatan, para pejabat kesultanan harus mencari sendiri sumber keuangan dari hak-hak istimewa yang diberikan sultan. Kekayaan para bangsawan ini dapat berupa uang tunai atau barang yang bersifat mobil, mudah disembunyikan atau dibawa ke tempat lain sehingga sukar diawasi.

Penduduk ibu kota di masa kesultanan dibagi dalam dua golongan yaitu miji dan alingan yang di bawah pengaruh para patron mereka, yaitu mantri dan priyayi yang biasanya langsung di bawah perintah Sultan. Miji tidak perlu membayar pajak tetapi harus membantu pelindungnya dalam tugas yang diberikan sultan. Miji yang menjadi bawahan mantri dapat juga mempunyai bawahan yang disebut Alingan untuk membantu Miji mengerjakan tugas-tugas yang diberikan mantri dari Sultan. Sebagai imbal baliknya, mantri harus bertanggung jawab memberikan perlindungan atas pengikut mereka. ${ }^{14}$

Sementara itu, para bangsawan yang tidak ditugaskan menjadi jenang, atau jabatan lainnya pada umumnya mendapat penghasilan dari pekerjaannya sebagai pengrajin emas, perak, tikar, atau berdagang. Kepengusahaan tersebut terus menerus berkembang dan mencakup puluhan jenis usaha dengan melibatkan ribuan miji. Setidaknya sejak masa berakhirnya Kesultanan Palembang menjadi tempat tumbuhnya berbagai jenis usaha dan keahlian yang terpusat dalam sistem guguk. Hasil-hasil kerajinan tangan tersebut dapat beredar dan diperdagangkan sampai ke Lingga, Malaka, Selangor, dan Jawa. ${ }^{15}$

Implikasi atas keuntungan distribusi ekonomi di antara kaum bangsawan berdiri suatu sistem distribusi simbol-simbol sosial yang memungkinkan para bangsawan membedakan gaya hidup mereka dari rakyat biasa sampai detail-detail yang kecil. Melalui kesenian para bangsawan dan anggota keluarga kesultanan mencitrakan keunggulan, kemegahan dan kewibawaan mereka sebagai kelompok lapisan atas masyarakat.

Selain itu, pada masyarakat Melayu pakaian berperan sebagai salah satu bagian yang penting dalam kebudayaan dan bukan sekadar kain pembungkus badan. Apa yang ditampilkan atau ditempelkan pada pakaian di setiap kelas masyarakat mencerminkan nilai sesungguhnya dari material bahan dan pekerja yang mengerjakannya. Lebih jauh lagi, pakaian merepresentasikan nilai simbol dan sakralitas yang tercermin pada motif, warna, dan desain. Simbolisasi status sosial pada pakaian nampak pada pemakaian kain songket di kalangan perempuan priyayi. Kreasi pada simbol dan kesenian dalam kerangka budaya dilihat sebagai sebuah perwujudan dari sebuah kapital budaya. Baik dalam bentuknya sebagai sebuah keahlian dan juga kepemilikan akan barang seni. Kesemuanya menjadi sebuah kapital di mana anggota masyarakat kemudian berebut untuk memperkaya dirinya dengan kapital tersebut, terlebih dalam masyarakat yang memandang seni sebagai sebuah kepakaran tersendiri yang unik dan bernilai tinggi. Tidak semua orang memiliki akses dan pengetahuan yang sama akan seni sehingga memiliki signifikansi yang berbeda.

Megumi Ichino mengutip keterangan R.H.M. Akib dalam bukunya Sejarah dan Budaya Palembang, mengenai pemakaian kain songket. Menurut R.H.M. Akib, songket merupakan pakaian tradisional Palembang yang dikenakan oleh perempuan bangsawan saat menghadiri upacara, pertemuan khusus di istana, dan saat menari untuk menyambut

\footnotetext{
${ }^{14}$ Peeters. Kaum tuo-kaum mudo... h, 14

${ }^{15}$ Mestika Zed. Kepialangan Politik dan Revolusi, Palembang 1900 - 1950 (Jakarta : LP3ES, 2003) h, 43.
} 
tamu penting. Laporan Praetorius dan pernyataan Akib diamini oleh Djohan Hanafiah pada tulisannya yang tidak dipublikasikan, draftnya didapatkan oleh Megumi saat penelitian di Palembang, mengenai fungsi pemakaian songket oleh perempuan bangsawan di masa kesultanan. ${ }^{16}$

Kain songket berbahan sutra dan dihiasi tenunan emas yang digunakan para priyayi dan kalangan istana merupakan produk terbaik, yang penenunannya dikerjakan oleh para penduduk perempuan yang berdiam di sekitar istana. Saat itu tenunan emas hanya boleh dikenakan kalangan bangsawan keraton. Kain songket berhias emas dikenakan oleh para perempuan bangsawan saat menghadiri upacara adat dan saat menari di istana. Corak dan tenunan emas pada pakaian perempuan bangsawan merepresentasikan kelas sosial kebangsawanan. Perempuan yang menggunakan gelar Ratu biasanya mengenakan songket lepus, songket yang setiap tenunannya berbahan emas. Sementara perempuan dari kelas bangsawan yang lebih rendah dengan gelar Raden Ayu mengenakan songket dengan tenunan emas tidak sebanyak kelas bangsawan di atasnya. Sementara kaum bangsawan pria memakai celana panjang, kain sarung yang dililit pendek, dan jas yang biasanya berhias tenunan mirip corak songket. ${ }^{17}$

\section{Jatuhnya Kedudukan Priyayi Palembang}

Sistem hubungan patron-klien menjadi ciri tradisi sosial politik feodalisme Kesultanan Palembang dan kesultanan lainnya di kawasan Asia Tenggara. Perkembangan hubungan patron-klien adalah proses politik utama yang mendasari pengembangan struktur kontrol sosial dan teritorial, seperti kepemimpinan kepala adat, aristokrasi dan kedaulatan. Hubungan patron-klien sebagai kasus khusus ikatan dyadic (dua orang) yang melibatkan relasi instrumental yang besar di mana seseorang dengan status sosioekonomi yang lebih tinggi menggunakan pengaruh dan sumber dayanya untuk memberikan perlindungan dan manfaat bagi orang yang statusnya lebih rendah (klien) yang, pada gilirannya, menggantinya dengan menawarkan dukungan dan bantuan umum, termasuk pelayanan kepada pelindung tersebut. ${ }^{18}$

Hubungan ini membentuk dasar organisasi politik, karena kelompok yang terhubung oleh ketergantungan di sekitar pelindung, sehingga menimbulkan apa yang disebut 'pengikut'. Hubungan patron-klien mengembang menjadi struktur berlapis karena patron juga bisa menjadi klien dari tokoh lainnya yang lebih kuat dan klien yang lebih hebat dapat menjadi pelindung orang-orang yang kurang kuat. Jaringan keterkaitan ini tidak hanya tahan lama, namun bersifat ekspansif, menghubungkan populasi besar di wilayah yang luas menjadi hierarki politik yang saling terkait. Dalam sistem sosial politik kesultanan terdapat hubungan antara sultan dan aparatnya. Sifat hubungan pribadi antara pejabat dan penguasa lokal dengan pribadi sultan, akhirnya sering dijamin melalui perkawinan dengan dinasti kerajaan. Dari proses inilah yang kemudian memunculkan kelompok priyayi. Struktur sosial di masyarakat Palembang saat itu terbagi dalam beberapa tingkatan yang setiap tingkatan mempunyai implikasi pada akses ekonomi, basis material, dan simbol kultural yang muncul.

\footnotetext{
${ }^{16}$ Megumi Uchino. Songket of Palembang : Socio Cultural and Economic Change in South Sumatran Textile Tradition. (Phd Thesis in South East Asian Studies, University of Hull, 2006), h, 11. Mengenai tulisan Djohan Hanafiah yang tidak dipublikasikan tersebut dapat diperiksa pada bagian daftar pustaka pada tulisan Megumi.

${ }^{17}$ Megumi Uchino. Songket of Palembang... h, 7

18 J.H. Walker. "The Meaning of Politics and The Mechanics of Meaning" dalam Australian Journal of Political Science, Vol.30, 1995.
} 
Kaum ningrat menempati tempat tertinggi dalam tata urutan sosial. Lapisan atas aristokrasi ini dibentuk oleh golongan priyayi, yang terdiri atas keturunan raja. Seorang sultan mempunyai kedudukan keramat, tetapi juga para pangeran, dan pejabat-pejabat lain dalam negara. Gelar sakral juga disesuaikan dengan kedudukan, tinggi atau rendah, besar dan kecilnya kekuasaan, dekat atau jauhnya seseorang dari sultan. Gelar-gelar itu datang dan bersumber dari sultan, antara aparat negara dan sultan ada hubungan pribadi dan sesuatu yang objektif seperti kedinasan, seperti Tumenggung, Demang, Ngabehi, dan Rangga. ${ }^{19}$

Sesudah pemerintah kolonial mengambil alih kekuasaan terjadi perubahan tak terelakan dialami kaum ningrat. Direbutnya keraton Palembang oleh Belanda pada 1821 tidak saja mempunyai dampak politik dan ekonomi, tetapi juga berdampak mendalam pada kebudayaan keraton Palembang selain mengakibatkan keruntuhan istana secara fisik. Selama masa awal penegakan kekuasaan kolonial, Belanda berusaha hati-hati memperlakukan para bangsawan. Kelompok aristokrat masih digunakan oleh pemerintah kolonial sebagai perantara antara otoritas baru itu dengan masyarakat. Namun pengaruh aristokrat sedikit demi sedikit dipreteli karena Belanda masih menaruh kecurigaan jika kalangan keraton tersebut akan memberontak.

Berbeda dengan metode politik pemerintah kolonial Belanda di Pulau Jawa yang menggunakan para bangsawan priyayi dan memasukannya menjadi bagian dari birokrasi pemerintahan. Sebelum periode kekuasaan kolonial, para priyayi ialah para penguasa setempat, penghubung antara raja dan rakyat. Mereka bertugas mengumpulkan upeti, mengorganisasi kerja bakti, memobilisasi rakyat dalam peperangan dan lain-lain. ${ }^{20}$ Apa yang terjadi di Palembang sedikit berbeda, selepas penghapusan Kesultanan Palembang, pada awalnya Belanda memerintah secara langsung, mengontrol wilayah, memungut pajak, dan melakukan perniagaan tanpa harus mempertahankan struktur feodal, kecuali di daerah pedalaman sebagai sumber komoditas perdagangan yang patronasenya tetap dijaga setelah berhasil mengalihkan kesetiaan elit pedalaman kepada Belanda. Tidak banyak bangsawan terutama di kota Palembang yang mendapat tempat di dalam pemerintahan, dan tidak lagi dapat mempertahankan posisi elit di tengah masyarakat.

Dibuangnya sultan beserta keluarga disusul dengan penghapusan kesultanan pada 1823 telah berakibat jauh bagi kaum elit lama di Palembang. Setelah sultan dan keluarga dibuang keluar Palembang, di Palembang masih tinggal sekitar 200 orang yang bergelar pangeran, di antara mereka para saudara Sultan Mahmud Badaruddin dan Sultan Ahmad Najamuddin III. Pangeran-pangeran ini masih mempunyai pengikut yang dipersatukan oleh rasa benci yang mendalam kepada pemerintah kolonial. Untuk mencegah mereka merasa terancam karena hak istimewa mereka dihapuskan, sebagai ganti rugi pemerintah kolonial menciptakan suatu sistem pensiun untuk para bangsawan Palembang. Sesudah kedua sultan Palembang disingkirkan pada 1824, pembayaran ini tetap dilakukan kepada bangsawan yang terkemuka. Langkah tersebut bertujuan untuk mengikis pengaruh priyayi atas penduduk kota. Pada 1840 tercatat terdapat 40 nama bangsawan yang berhak menerima ganti rugi tersebut.

Pihak yang paling naas ialah keluarga sultan yang kembali dari pengasingan di Ternate yang harus hidup dengan tunjangan kecil. Penurunan ekonomi ini menyebabkan para priyayi tersebut tidak dapat mempertahankan pengikut mereka dan pengaruhnya

\footnotetext{
${ }^{19}$ Hanafiah. Melayu-Jawa... h, 175.

${ }^{20}$ Ong Hok Ham. Dari Soal Priyayi Sampai Nyi Blorong : Refleksi Historis Nusantara (Jakarta : Penerbit Buku Kompas, 2002) h, 10.
} 
hilang sama sekali sehingga tidak mempunyai kekuatan politik apapun. Tunjangan pensiun yang berasal dari pemerintah kolonial untuk para priyayi generasi pertama tidak dapat diwariskan, bahkan untuk generasi berikutnya, karena bagi pemerintah Belanda keturunan para priyayi ini dianggap tidak lagi memiliki keistimewaan bahkan masuk dalam register pajak, yang oleh sebagian besar keluarga priyayi dianggap sebagai penghinaan. $^{21}$

Hubungan patronase mulai diakhiri secara resmi ketika pola sosial seperti miji dan alingan terkikis akibat dari kebijakan pemerintah kolonial dan di mana pajak-pajak istimewa kaum priyayi kemudian diganti dengan pembayaran pensiun yang diberikan kepada sebagian kecil keluarga bangsawan. Perubahan ini mengakibatkan berkurangnya sumber kekuasaan material kaum priyayi dan tidak dapat lagi mempertahankan diri sebagai pelindung politik bagi para pengikutnya. Lama-kelamaan kelompok priyayi ini mulai mengalami kemiskinan dan berusaha mati-matian memelihara kedudukan sosial mereka.

Di depan umum, para priyayi masih mencoba mempertahankan kedudukan mereka, tetapi di balik topeng sosial ini sering bersembunyi kehidupan yang miskin. Akibat anjloknya perekonomian yang dialami keluarga-keluarga bangsawan yang menetap di Palembang kemudian muncul sebutan "buntung" yang merupakan cibiran bagi orang-orang yang pernah mengalami kejayaan namun kemudian mengalami kepahitan ekonomi. Kenangan akan kekayaan dan kejayaan masa lalu tertanam kuat dalam memori kolektif orang asli Palembang, terutama dari keluarga priyayi. Dalam alam pikirannya mereka merasa seakan masih berkuasa atas rakyat biasa dan orangorang pendatang, terutama orang Uluan yang lebih berhasil secara ekonomi di masa kolonial, meski realita sesungguhnya orang-orang yang dulu pernah menempati strata atas itu tengah dihimpit kesulitan ekonomi. ${ }^{22}$

\section{Perubahan Sosial dan Kebudayaan}

Kevakuman sosial sebagai akibat dari degradasi sosial kaum priyayi Palembang kemudian memunculkan dinamika sosial baru yang tidak lagi didasarkan pada struktur feodal kesultanan yang semakin menghilang. Meski Belanda berhasil menguasai militer dan politik Palembang, namun tidak dapat dikatakan bahwa orang-orang kulit putih tersebut mempunyai pengaruh terhadap kehidupan sosial masyarakat Palembang. Faktor yang mendorong perubahan sosial-budaya di Palembang masih berasal dari luar, konsekuensi dari arus migrasi para pedagang yang berasal dari Hadramaut.

Konstruksi sosial-ekonomi Palembang sebagai kota dagang semakin mendapat tempatnya ketika pemerintah kolonial semakin memperkokoh perekonomian. Orangorang Arab serta Timur Asing lainnya mendominasi perdagangan komoditas alam, kain dan tekstil serta kapal dan pengusahaan kayu. Hasil pertanian seperti lada, dan kopi membuat Palembang menjadi kota dagang yang ramai dibanding masa kesultanan. Petani yang berasal dari pedalaman Palembang membawa seluruh hasil tanaman dagang ke Palembang, sebaliknya para pedagang menikmati untung melalui tukar menukar komoditas.

Munculnya para pedagang Arab sebagai konsekuensi daya tarik Palembang sebagai kota dagang. Sebelum abad ke-19, para pedagang dari Hadramaut datang ke Sumatra dalam jumlah kecil. Gelombang pedagang Arab datang dengan jumlah yang lebih besar setelah dibukanya Terusan Suez pada 1869 yang semakin mendorong

\footnotetext{
${ }^{21}$ Peeters. Kaum tuo-kaum mudo... h, 26.

${ }^{22}$ Dedi Irwanto. Venezia Dari Timur... h, 111.
} 
munculnya kota-kota dagang kolonial. Setelah menetap di sebuah kota pada umumnya para pedagang Arab ini berdiam membangun pemukiman tersendiri yang pada awalnya terpisah dari penduduk setempat. Selain karena alasan kekerabatan, terkonsentrasinya pemukiman pedagang Arab juga ikut didorong oleh kebijakan pemerintah kolonial yang membentuk pola tata ruang sesuai dengan kebijakan segregasi sosial. ${ }^{23}$

Jatuhnya keraton dengan segala implikasi sosialnya membuka jalan bagi para sayid untuk semakin menunjukan dominasinya di bidang keagamaan dan budaya. Perubahan pola keagamaan dimotori modal ekonomi para pedagang arab. Biasanya para sayid membangun rumah ibadah atau langgar di wilayahnya sendiri yang tidak hanya berfungsi sebagai tempat ibadah, tetapi juga sebagai ruang pengajaran agama sekaligus ruang strategis penyebaran budaya. Penduduk kampung sekitar kediaman sayid terutama yang perekonomiannya tergantung pada aktivitas perdagangan dari para pedagang arab adalah kelompok pertama yang ditujukan pada pola islamisasi para sayid. Penduduk dari strata sosial yang rendah pada akhirnya mengikuti pola kebudayaan religius para pedagang Hadrami yang menapaki status kalangan atas di Palembang. Melalui strategi budaya ini sayid memperkuat modal agama sebagai topangan memperluas pengaruhnya. ${ }^{24}$

Semakin banyaknya para pedagang arab yang mencapai lapisan atas mulai menarik ketertarikan kelompok sosial lainnya pada pola kebudayaan bergengsi ini. Setelah kekuasaan politik tidak lagi dipegang oleh kalangan keturunan keraton, di kalangan bangsawan sendiri mulai mencari kiblat pada pola budaya lain sebagai penanda prestise alternatif. Para keturunan priyayi dan para pedagang kaya dari kalangan penduduk asli Palembang melihat praktek budaya para sayid sebagai sesuatu yang dapat ditiru. Bahkan perkawinan antara keturunan sayid dan anak dari priyayi semakin jarang terjadi karena anak priyayi tidak lagi dianggap sebagai golongan terhormat. Para sayid lebih memilih menikahkan anaknya dengan keturunan sayid dari daerah lain daripada harus menikahkannya dengan orang Palembang meski keturunan priyayi. $^{25}$

Peningkatan ritual agama dan simbol-simbol keislaman menjadi sesuatu yang semakin digenggam oleh kalangan priyayi sebagai upaya untuk tetap mendapat perlindungan serta mempertahankan pengaruhnya di hadapan kelompok sosial lainnya. Simbol agama tidak hanya berputar pada ritual, aktivitas wakaf dilakoni oleh para priyayi yang serta merta merubah pola ruang. Nilai-nilai budaya keraton mengalami penurunan bagi para priyayi itu sendiri di tengah karakter masyarakat yang melihat budaya pada lekatannya dengan basis material. Meskipun budaya keraton masih dipegang "keasliannya" sebagai penanda dan klaim identitas ketika berhadapan dengan kelompok "orang kaya baru" dari daerah pedalaman.

Dihapuskannya Kesultanan Palembang Darussalam dan berlakunya sistem pemerintahan langsung yang di Kota Palembang telah membawa kemerosotan

\footnotetext{
${ }^{23}$ Frode H. Jacobsen. Hadrami Arabs in Present-Day Indonesia : An Oriented Arab Group With An Arab Signature (Oxon : Routledge Contemporary Southeast Asian Series, 2009) h, 15.

${ }^{24}$ Peeters. Kaum tuo-kaum mudo... h, 21

${ }^{25}$ Para saudagar Arab di Palembang menjadi lebih memilih menikahkan anaknya dengan keturunan arab lainnya dari wilayah lain seperti Singapura. Dominasi keluarga-keluarga Arab pada perdagangan di Singapore diawali datangnya Syech Mohammad bin Harun al Juneid dan keponakannya, Syech Omar bin Ali al-Juneid yang keduanya datang dari Palembang pada 1819, saat tensi ketegangan antara kesultanan Palembang dan Belanda tengah memanas. Keluarga al-Juneid dan keluarga lainnya seperti al-Kaff dan As-Seggaf menjadi keluarga-keluarga Arab kaya terpandang di Singapura. Lihat : Ameen Ali Talib. "Hadramis in Singapore" dalam Journal of Muslim Minority Affairs, 17:1, 1997. h, 89-96.
} 
kelompok elit yang tidak lagi dapat mempertahankan simbol-simbol kapital budaya lama mereka sebagai masyarakat lapisan atas. Akibatnya kesenian yang berasal dari budaya Kesultanan Palembang berkurang seiring dengan runtuhnya struktur kekuasaan priyayi Palembang. Ketika struktur tersebut tidak lagi menjadi penyokong kekuasaan, priyayi dihadapkan pada kondisi yang mengharuskan mereka mencari sokongan legitimasi yang melekat pada bentuk yang lain, yakni ruang keagamaan. Nilai kesenian dan budaya keraton turun di kalangan priyayi sendiri. Pengaruh Islam pada kesenian di Palembang tidak terletak pada pembatasan yang diberlakukan melalui pelarangan, namun melekat pada transformasi sosial yang dialami masyarakat Palembang.

\section{Kesimpulan}

Ritual dan kesenian yang hidup di masa Kesultanan Palembang hampir tidak tersisa di masa modern setidaknya dikarenakan dua faktor, pertama kaum ningrat lama yang berasal dari keturunan raja tidak dapat mempertahankan gaya hidup keraton setelah hilangnya hak-hak istimewa mereka sebagai sumber ekonomi. Sementara itu, muncul elit-elit baru yang muncul sebagai konsekuensi perdagangan. Kelompok elit baru ini bukan berasal dari kalangan keturunan keraton dan tidak menggunakan simbol-simbol lama untuk menunjukan status sosialnya. Meningkatnya keislaman di Palembang menjadi faktor lain yang juga diikuti dengan tidak digunakan laginya simbol-simbol feodal lama. Kaum priyayi kehilangan wibawa ekslusif mereka atas penduduk kota lainnya dan sedikit demi sedikit mengalami kebangkrutan akibat ketidakmampuan mereka beradaptasi dengan perkembangan ekonomi Palembang. Lama kelamaan keistimewaan kelompok bangsawan ini tergerus dan anjlok tidak ada bedanya dengan masyarakat biasa.

Sulitnya menelusuri kesenian asli Palembang sangat berkaitan dengan sejarah "agen" pembawa kesenian adiluhung tersebut, yakni kelas ningrat, kelompok priyayi yang menunjukan kewibawaan kuasa mereka salah satunya melalui seni. Seni di sini dilihat sebagai signifikasi yang memperlihatkan bentuk-bentuk dominasi dan kekuasaan sekaligus menopang relasi antara agen dan struktur. Melalui relasi tersebut seorang agen harus mampu menggunakan sederet kekuasaan kausal, termasuk mempengaruhi kekuasaan-kekuasaan yang dijalankan oleh pihak lain. Kekuasaan dalam sistem-sistem sosial yang memiliki suatu kontinuitas di sepanjang ruang dan waktu mengandaikan rutinisasi relasi-relasi kemandirian dan ketergantungan di antara para aktor atau kelompok dalam konteks-konteks interaksi sosial. Oleh karena itu, seorang agen tidak lagi mampu berperan demikian jika dia kehilangan kemampuan untuk mempengaruhi yaitu menggunakan suatu jenis kekuasaan.

Pernyataan bahwa ajaran Islam menjadi faktor utama begitu terbatasnya kesenian di Palembang telah mengabaikan beberapa hal. Pertama, diabaikannya perubahan yang terjadi antara keruntuhan kesultanan dengan zaman modern, yang justru dalam rentang waktu tersebut Palembang mengalami dinamika sosial yang luar biasa. Termasuk dalam ruang kesenian di mana pengaruh perubahan tersebut yang dapat menjelaskan bagaimana konstruksi kesenian di Palembang sekarang. Kedua, kekuasaan Kesultanan Palembang dianggap statis, konstan, dan penetrasinya kuat di seluruh wilayah kekuasaannya mencakup segala lapisan sosial yang beragam, sehingga tidak melihat bagaimana mekanisme kekuasaan tersebut dijalankan secara konkret. Lebih jauh lagi, Islamisasi yang terjadi di Palembang dianggap telah beres pada saat Kesultanan Palembang padahal gelombang islamisasi setelah keruntuhan kesultanan adalah yang membentuk wajah islam di Palembang seperti sekarang. 


\section{Buku}

\section{Daftar Pustaka}

Abels, Birgit (ed). Austronesian Soundscapes: Performing Arts in Oceania and Southeast Asia. Amsterdam : Amsterdam University Press. 2011.

Barnard, Timothy P (ed). Contesting Malayness : Malay Identity Across Boundaries. Singapore : Singapore University Press, 2006.

Bourdie, Pierre. Distinction : A Social Critique of The Judgement of Taste (translated by Richard Nice). Cambridge : Harvard University Press, 1984.

Drakard, Jane. A Malay Frontier : Unity and Duality in a Sumatran Kingdom. Ithaca : South East Asia Program, 1990.

Gadjahnata, KHO dan Sri Edi Swasono (ed). Masuk dan Berkembangnya Islam di Sumatera Selatan. Jakarta : Penerbit Universitas Indonesia, 1986.

Hall, Stuart and Paul Du Gay. Representations: Cultural Identity and Signifying Practices. London: Sage Publication, 2003.

Hanafiah, Djohan. Melayu-Jawa : Ciri Budaya dan Sejarah Palembang .Jakarta : PT Raja Grafindo Persada bekerja sama dengan Pemerintah Daerah TK II Kotamadya Palembang, 1995.

Harnish, David D. and Anne K. Rasmussen (ed). Divine Inspirations : Music and Islam in Indonesia. Oxford University Press, 2011.

Jacobsen, Frode H. Hadrami Arabs in Present-Day Indonesia : An Oriented Arab Group With An Arab Signature. Oxon : Routledge Contemporary Southeast Asian Series, 2009

Kartomi, Margaret. Musical Journey In Sumatera. Chicago : University of Illinois, 2012.

Marsden, William. Sejarah Sumatra. Depok : Komunitas Bambu, 2013.

Ong Hok Ham. Dari Soal Priyayi Sampai Nyi Blorong : Refleksi Historis Nusantara. Jakarta : Penerbit Buku Kompas, 2002.

Peeters, Jeroen. Kaum Tuo - Kaum Mudo : Perubahan Religius di Palembang 18211942. Jakarta : INIS, 1997.

Purwanto, Bambang. From Dusun To Market : Native Rubber Cultivation in Southern Sumatra, 1890-1940. PhD Thesis in School of Oriental and African Studies, University of London, 1992.

Rasmussen, Anne K. Women, the Recited Quran, and Islamic Music in Indonesia. Berkeley : University of California Press, 2010.

Reid, Antony. Menuju Sejarah Sumatra : Antara Indonesia dan Dunia. Jakarta : Yayasan Obor Indonesia dan KITLV, 2011.

Reid, Antony dan David Marr (ed). Dari Raja Ali Haji Hingga Hamka Jakarta : Grafiti Press, 1983. 
Santun, Dedi Irwanto Muhammad. Venesia Dari Timur : Memaknai Produksi dan Reproduksi Simbolik Kota Palembang Dari Kolonial Sampai Pascakolonial. Yogyakarta : Penerbit Ombak, 2010.

Sartono, Verbi Al Lintani, Yuli Sudartati. Tari Tanggai : Selayang Pandang. Palembang : Penerbit Dewan Kesenian Palembang, 2007.

Spillers, Henry. Gamelan : The Traditional Sounds of Indonesia. California : ABC CLIO, 2004.

Uchino, Megumi. Songket of Palembang : Socio Cultural and Economic Change in South Sumatran Textile Tradition. Phd Thesis in South East Asian Studies, University of Hull, 2006.

Wargadalem, Farida R. Kesultanan Palembang Dalam Pusaran Konflik (1804-1825). Jakarta : KPG, 2017.

Zed, Mestika. Kepialangan Politik dan Revolusi, Palembang 1900 - 1950. Jakarta : LP3ES, 2003.

\section{Artikel Dalam Jurnal}

Bohlman, Philip V. "Music as Representation", dalam Journal of Musicological Research, 24:3-4, 2005.

Braginsky, Vladimir and Anna Suvorova. "A New Wave of Indian Inspiration : Translations from Urdu in Malay Traditional Literature and Theatre" dalam Indonesia and the Malay World, 36:104, 2008.

Asia" dalam Middle Eastern Literatures, Vol. 7, No. 2, July 2004.

Glover, Ian C. "National and political uses of archaeology in South-East Asia" dalam Jurnal Indonesia and the Malay World, Vol. 31, No. 89, March 2003

Kartomi, Margaret. "Paradox and Nostalgie History of "Gending Sriwijaya" in South Sumatra" dalam Archipel, Volume 5. 1993.

Manguin, Pierre Yves. "Welcome to Bumi Sriwijaya or The Building of a Provincial Identity in Contemporary Indonesia " dalam Asia Research Institute Working Paper Series No. 102, 2008.

McCallum, Jenny. "Beguiling Voices: Traces of Vocality in the Malay Literary Tradition of the Riau Islands" dalam proceeding Ethnomusicology Forum, 2017

Reid, Antony. "Understanding Melayu (Malay) as A Source of Diverse Modern Identities" dalam Journal of Southeast Asian Studies, volume 32 (2), 2001.

Slama, Martin. "Translocal Network and Globalisation Within Indonesia : Exploring the Hadrami Diaspora from the Archipelago's North East" dalam Asian Journal of Social Science No. 39, 2011.

Talib, Ameen Ali "Hadramis in Singapore" dalam Journal of Muslim Minority Affairs, 17:1, 1997.

Walker, J.H. "The Meaning of Politics and The Mechanics of Meaning" dalam Australian Journal of Political Science, Vol.30, 1995. 